


\title{
Comparative legal analysis of the anti- corruption policy in Ukraine and Poland
}

\author{
DOI: https://doi.org/10.46398/cuestpol.3969.05
}

\author{
Oleksandra Zakharova * \\ Olena Harasymiv ** \\ Olga Sosnina *** \\ Oleksandra Soroka **** \\ Inesa Zaiets $* * * *$
}

\begin{abstract}
Effective counteraction to corruption remains relevant in some countries of Eastern Europe and the former Soviet Union, given that manifestations of corruption are a real obstacle to the realization of human rights, social justice, economic development and jeopardizes the proper functioning of a market economy. However, if such countries of the region, such as Poland, succeeded in ensuring the implementation of an effective anticorruption policy, a number of post-Soviet countries, in particular Ukraine, faced significant obstacles to overcoming corruption and effectively implementing national anti-corruption policies. Therefore, within this article, a comparative legal analysis of the anti-corruption legislation of these countries has been carried out. The state of implementation of national anti-corruption policies and the formulated conclusions, which provide answers to the questions of improving the implementation of national anti-corruption policy, in particular Ukraine, are considered. Thus, the existence of modern national anti-corruption legislation that best meets the requirements and recommendations on which the state relies on relevant international treaties can be the key to successful anti-corruption
\end{abstract} efforts.

* Candidate of Science in law, Associate Professor of the Department of Criminal Process and Forensics, Lviv State University of Internal Affairs, Lviv, Ukraine, ORCID ID: https://orcid.org/oooo-0oo16623-9004. Email: 0607oleksandra@gmail.com

** Candidate of Science in law, Associate Professor of the Department of Criminal Process and Forensics, Lviv State University of Internal Affairs, Lviv, Ukraine, ORCID ID: https://orcid.org/oooo-00024588-9531. Email: Garsumiv_@ukr.net

*** Candidate of Science in law, Deputy Head of the Department for Educational and Methodological Work of Criminal Law and Procedure, Lviv University of Trade and Economics, Lviv, Ukraine, ORCID ID: https://orcid.org/oooo-0002-0033-4487. Email: i.am.sosnina.olga@gmail.com

**** Candidate of Science in law, Head of the educational and methodical center of the International European University, Kyiv, Ukraine, ORCID ID: https://orcid.org/oooo-0002-9958-6907. Email: oleksandrasoroka@ieu.edu.ua

***** Candidate of Science in law, Researcher of the Department of organization of scientific activity and protection of intellectual property rights, National Academy of Internal Affairs, Kyiv, Ukraine, ORCID ID: https://orcid.org/oooo-00o3-0159-4747. Email: zinessa99@gmail.com 


\section{Oleksandra Zakharova, Olena Harasymiv, Olga Sosnina, Oleksandra Soroka y Inesa Zaiets

Keywords: anti-corruption policy; Eastern Europe; legal analysis; prevention of corruption; specialized anti-corruption body.

\section{Análisis jurídico comparativo de la política anticorrupción en Ucrania y Polonia}

\section{Resumen}

La lucha eficaz contra la corrupción sigue siendo pertinente en algunos países de Europa oriental y la ex Unión Soviética, dado que las manifestaciones de corrupción son un obstáculo real para la realización de los derechos humanos, la justicia social y el desarrollo económico y ponen en peligro el funcionamiento adecuado de una economía de mercado. Sin embargo, si esos países de la región, como Polonia, lograron garantizar la implicacion de una política anticorrupción eficaz, varios países postsoviéticos, en particular Ucrania, se enfrentaron a obstáculos importantes para superar la corrupción y aplicar eficazmente la lucha nacional contra políticas de corrupción. Por ello, dentro de este artículo se ha realizado un análisis jurídico comparativo de la legislación anticorrupción de estos países. Se considera el estado de implicacion de las políticas nacionales anticorrupción y las conclusiones formuladas, que brindan respuestas a las preguntas sobre la mejora de la implicacion de la política nacional anticorrupción, en Ucrania particularmente. Por lo tanto, la existencia de una legislación nacional anticorrupción moderna que cumpla mejor con los requisitos y recomendaciones en los que el estado se basa en los tratados internacionales relevantes puede ser la clave para el éxito de los esfuerzos anticorrupción.

Palabras clave: política anticorrupción; Europa del Este; análisis legal; prevención de la corrupción; organismo especializado en lucha contra la corrupción.

\section{Introduction}

After the fall of the communist regime in Eastern Europe and the former Soviet Union in the early 1990 s, as a rule, representatives of other political parties came to power democratically in these countries. They eventually began to introduce a new economic, political, and social course there. The introduction of market relations, the sale of state-owned property to private companies, the creation of new forms of economic relations (for example, private-public partnership) in which the state participates through its 
representatives have even more actualized the issues of combating and preventing corruption in new political, economic, social and legal conditions of existence. In the article, we will carry out a comparative legal analysis of modern anti-corruption programs (strategies) that are being implemented in Ukraine and Poland, as well as estimate their effectiveness and results of their implementation.

The World Bank determines that corruption is commonly defined as the abuse of public or corporate office for private gain. Instead, Christensen, Shaxon and Baker, point out the definition of corruption according to Transparency International (TI) as "the abuse of entrusted power for private gain". They rightly point out that this definition is better, as it could be used more broadly, but in practice, it is usually interpreted in a narrow way, notably by focusing on the public sector, particularly on bribery (Christensen et al., 2008). Civil Law Convention on Corruption (1999), ratified, in particular by Poland (2002) and Ukraine (2005), states that corruption means 'requesting, offering, giving or accepting, directly or indirectly, a bribe or any other undue advantage or prospect thereof, which distorts the proper performance of any duty or behavior required of the recipient of the bribe, the undue advantage or the prospect thereof'. Corruption represents a major threat to the rule of law, democracy and human rights, fairness and social justice, hinders economic development and endangers the proper and fair functioning of market economies (Civil Law Convention on Corruption, 1999). Corruption is not only illegal but also not a completely moral act. In this view, morality and law are a supportive factor of each other, global morality is a criterion of standard behavior for the introduction of such norms of law (Obura, 2014). In a democratic system based on people's trust, the spread of injustice may become fatal, because it destroys the faith in the institutions of power (De Vel and Csonka, 2002, p. 361).

The criticality of corruption in modern Ukraine is due to the problem of the formation of civil society, the weakness of its structures, and the inability to withstand the pressure of the shadow economy. According to research, corruption was one of the reasons that led to the Revolution of Dignity in Ukraine in 2013-2014 (Bardachov, 2014). The high level of corruption in Ukraine confirms by the Corruption Perceptions Index (CPI). According to the CPI, Ukraine ranked 114th among the 180 countries surveyed in 2019 (Transparency International, 2020).

Vice versa, Poland, which in the early 1990's also lost its communist regime. According to the CPI, Poland ranked relatively high, which can be evidence of the effectiveness of anti-corruption programs by Polish state institutions. Although CPI has been subjected to sustained critique for distorting and manipulating the measurement and understanding of corruption (Poynting and Whyte, 2017). Johnston offered the argument 
that four major syndromes of corruption can be observed in all countries. Following the proposed division, Poland suffers from 'Elite Cartels' syndrome, and Ukraine deals with 'Oligarchs and Clans' syndrome. It is due to the small number of contentious elites, very weak institutions, rapidly expanding opportunities, and pervasive insecurity. The existence of such a separation leads to successful reform or best practice in Country A may be impossible in Country B, irrelevant in Country C, and downright harmful in Country D (Johnston, 2011). Nonetheless, CPI results are used by both international and national organizations and corporations. These findings are confirmed, in particular, by statistical data, according to which only $15 \%$ of Poles regard corruption as one of the most serious problems in the country (Banakhievich, 2017). 33 \% of the Ukrainians consider corruption as an element of tradition (Polikovskaya, 2017).

The choice of Ukraine and Poland for this research is because, on the one hand, Ukraine (EU-Ukraine Association Agreement) and Poland (EU member state), having a close geographical position. They have similar socialist past, since the 1990 s, started an active transformation of their legal institutions. On the other hand, these countries have so far achieved different results in the implementation of their anti-corruption policies. The purpose of this study is to get an answer: how the legislative process can influence the perception and success of national anti-corruption policy implementation of such similar countries. The conduct of comparative legal analysis of the anti-corruption policy in these countries allows, in particular, to identify and determine the degree of influence of individual elements of the anti-corruption policy on the success of anti-corruption policy implementation. The impact of international anti-corruption treaties on the results of national anti-corruption policy implementation was also evaluated.

We propose to conditionally divide this article of three main sections. The first outlines the main modern legislative principles of anti-corruption policy in such countries of Eastern Europe as Poland and Ukraine. In this section, the comparative analysis of the national anti-corruption legislation carries out. There examine its links with the main international agreements on preventing and combating corruption, which these countries have joined, as well as analyze the state of national anti-corruption policies implementation, factors, which affect it. The second section provides data on anti-corruption strategies, programs, and their implementation in these countries. In the final section, based on the results of the comparative legal analysis, the main findings of the research do formulate and summarized. 


\section{Methodology of the study}

The methodological basis of this work is philosophical methods: dialectical (the basic principles of which are objectivity, comprehensiveness, concreteness and completeness of knowledge's etc.), logical (the main methods of which are analysis and synthesis, induction and deduction, analogy), etc.

Firstly, the dialectical method revealed general features, connections and regularities in the formation of anti-corruption measures taking into account the norms of international law. The hermeneutic method allowed to study the content of certain legal norms and theoretical provisions in the context of topical issues of anti-corruption measures on the basis of acquaintance with the texts of normative and doctrinal sources. The analysis and synthesis allowed to comprehensively describe and characterize the essence of the anti-corruption policy of Poland and Ukraine, to combine original ideas, principles and developments for further effective use of legal positions in anti-corruption policy at the level of individual countries.

Also, the use of the formal-legal method made it possible to determine the list of specific tasks, deadlines, bodies responsible for each task, efficiency indicators, sources of funding, providing clear indicators for assessing the success of the implementation of anti-corruption state strategy in Poland and Ukraine. Thanks to the comparative legal method, it has become possible to compare the main legal positions in the regulation of anticorruption processes, taking into account the peculiarities of combating this phenomenon at the national and international levels. The logical-legal method helped formulate proposals for the use guiding anti-corruption principles applied at the Council of Europe level.

Furthermore, the special legal method was used in assessing the effectiveness of the an overview of anti-corruption strategies and programs, as well as the state of their implementation in Ukraine and Poland. Finally, generalization, as a method, allowed to identify the main problems and formulate the vectors of Ukraine's implementation of national anticorruption policy, taking into account the experience of Poland and other developed countries.

\section{Results and Discussion}

Before moving directly to the comparative legal analysis of the national legislation of Ukraine and Poland, let us draw attention to the importance of the existence of legal mechanisms that provide an integrated approach to preventing and combating corruption both at the international and national levels. 
Oleksandra Zakharova, Olena Harasymiv, Olga Sosnina, Oleksandra Soroka y Inesa Zaiets Comparative legal analysis of the anti-corruption policy in Ukraine and Poland

\subsection{International level}

At the level of the Council of Europe (Ukraine and Poland is its members), the anti-corruption principles approved by Resolution (97) 24 on the Twenty Guiding Principles for the Fight Against Corruption. These include, among others, such as:

- to take effective measures for the prevention of corruption and, in this connection, to raise public awareness and promoting ethical behaviour;

- to ensure co-ordinated criminalisation of national and international corruption;

- to ensure that those in charge of the prevention, investigation, prosecution, and adjudication of corruption offences enjoy the independence and autonomy appropriate to their functions, are free from improper influence and have effective means for gathering evidence,protecting the persons who help the authorities in combating corruption and preserving the confidentiality of investigations;

- to provide appropriate measures for the seizure and deprivation of the proceeds of corruption offences;

- to promote the specialisation of persons or bodies in charge of fighting corruption and to provide them with appropriate means and training to perform their tasks.

- to ensure that the system of public liability or accountability takes account of the consequences of corrupt behaviour of public officials.

- to encourage the adoption, by elected representatives, of codes of conduct and promote rules for the financing of political parties and election campaigns which deter corruption.

- to encourage research on corruption.

- to develop to the widest extent possible international co-operation in all areas of the fight against corruption (Resolution (97) 24, 1997). Such anti-corruption principles must be implemented in the national legislation and the law enforcement practice of each party country. Further, the legislative acts of Ukraine and Poland, which introduce anti-corruption principles, are listed in the article.

Taking into account Resolution (97) 24, the Committee of Ministers of Council of Europe was resolved to establish the Group of States against Corruption (GRECO), governed by the Statute appended thereto (Resolution (99) 5, 1999). Currently, GRECO comprises 49 member States (48 European States and the United States of America). Poland (1999), 
Ukraine (2006), RF (2007) also joined GRECO. The aim of the GRECO is to improve the capacity of its members to fight corruption by following up, through a dynamic process of mutual evaluation and peer pressure, compliance with their undertakings in this field. In order to achieve the aim, the GRECO shall monitor the observance of the Guiding Principles for the Fight against Corruption (Appendix to Resolution (99) 5, 1999). The next stage of implementation of the provisions of Resolution (97) 24 was the Criminal Law Convention on Corruption, 1999. The Criminal Law Convention on Corruption has recommended that the participating countries take measures to establish in their national legislation criminal liability for a certain list of corruption offenses. The control over its implementation was entrusted to GRECO.

The UN Convention against Corruption, adopted in 2003, involves 186 States Parties, including Ukraine and Poland (Signature and Ratification Status, 2018). In accordance with Articles 5, 6 of this Convention each State Party shall, in accordance with the fundamental principles of its legal system, develop and implement or maintain effective, coordinated anti-corruption policies. Each State Party shall grant bodies that prevent corruption the necessary independence, in accordance with the fundamental principles of its legal system, to enable bodies to carry out their functions effectively and free from any undue influence (UN Convention against Corruption, 2003). The mentioned provision of the UN Convention against Corruption as regards the establishment of conditions for the independence of anticorruption bodies in its content corresponds to one of the principles previously stated, which were approved by Resolution (97) 24. This statement also applies to a number of other provisions set out in Resolution (97) 24 and UN Convention against Corruption.

Of course, there is an interdependence between international and national anti-corruption measures, since national anti-corruption policy must be constantly improved in line with international standards. However, despite the considerable potential of international legal instruments to fight corruption, national measures are the most efficient and effective methods of combating corruption (Conforty, 1993). Jeremy Pope highlights the need for a 'system of state integrity' using a holistic approach to addressing transparency and accountability issues. The approach embraces all key structures of democratic, legal, and civil society. In his view, the political struggle against corruption has several elements common to each country. It is the reform of key state programs, the change in the structure of the government and the improvement of its accountability, the change in moral and ethical attitude to corruption, and, most importantly, the involvement and support of the government, the private sector and civil society of anticorruption policy (Pope, 2011). World Bank's expert Pierre Landell-Mills is convinced of the need to adopt anti-corruption legislation. This legislation formed by laws on combating corruption, extortion and bribery, funding of 
Oleksandra Zakharova, Olena Harasymiv, Olga Sosnina, Oleksandra Soroka y Inesa Zaiets Comparative legal analysis of the anti-corruption policy in Ukraine and Poland

political parties, and laws aimed at curbing corruption. In particular: the introduction of free access of citizens to public information, guaranteeing the protection of persons from criminal prosecution who report cases of corruption, about conflict of interests (Landell-Mills, 2013).

\subsection{National level. Ukraine}

For today, the adoption of the "Prevention of Corruption" Act 2014 (Ukr) is the latest stage in the implementation of the anti-corruption policies contained in the international treaties to which Ukraine joined. Article 4 of this Act specifies that the central body of executive power with a special status, which ensures the formation and implementation of state anti-corruption policy, is the National Agency for Corruption Prevention (NACP). The Cabinet of Ministers of Ukraine creates the NACP. His powers include:

- analysis of prevention and counteraction to corruption, activities of state bodies and local self-government bodies in the relevant sphere.

- development of anti-corruption strategy and state program implementation, monitoring, coordination, and evaluation of the effectiveness of the Anti-Corruption Strategy.

- formation and implementation of anti-corruption policy, drafting of normative legal acts.

- monitoring and control over the implementation of legislation on ethical conduct, prevention, and resolution conflict of interests.

- control, verification, storage, and disclosure of officials' declarations and monitoring their lifestyles.

- maintenance of the Unified State Register of officials' declarations (USROD) and the Unified State Register of persons who have committed corruption offenses.

- approval of anti-corruption programs of state authorities and local self-government bodies.

- informing the public about measures of preventing corruption, implementation of measures aimed at forming a negative attitude towards corruption in the minds of citizens.

- coordination of international obligations implementation, cooperation with state bodies, non-governmental organizations of foreign states and international organizations.

Instead, before the start of the work of this newly created anticorruption body, in March 2016, MP V. Chumak, as a result of political pressure, refused to exercise the powers of a member of NACP. It led to 
the lack of a quorum and the impossibility of NACP at that time to start work. (Ukrainian Pravda, 2016). During 2016-2018, NACP, with almost 2 million, was able to check only 164 electronic declarations of officials. The reason for this was the lack of a comprehensive information security system in the software product, which was supposed to ensure the maintenance of USROD. The launch of the electronic declaration system was postponed until September 2016. Falkner and Treib describe some Eastern European member states (Hungary, Slovakia, Slovenia) as 'the world of dead letters' because the stage of practical implementation of EU Directives has flawed enforcement (Falkner and Treib, 2008). With similar examples, in relation to the stage of practical implementation of international anti-corruption legislation, Ukraine can also be referred to as the world of dead letters.

In November 2017, the head of the NACP department publicly accused the head of NACP Natalia Korchak of distorting the results of checking declarations of certain officials, as well as the unlawful influence on the activities of the NACP by the administration of the President of Ukraine (Hromadske TV, 2018). GRECO also turned attention to these facts: 'for the NACP to work effectively, it must be independent and free of any political interference both in law and, principally, in practice' (GRECO, 2017). So far, the law enforcement agencies not given a public assessment of procedural results of verifying these allegations.

The anonymous interview conducted with 42 detectives of the National Anti-Corruption Bureau of Ukraine (NABU) and 36 judges of Kyiv's region. Informed consent obtained from participants. $81 \%$ of detectives interviewed and $86 \%$ of judges interviewed think that the absence of non-procedural political influence is a prerequisite for the successful implementation of anti-corruption policies.

According to Art. 1 of "On the National Anti-Corruption Bureau of Ukraine" Act 2014 (Ukr), the National Anti-Corruption Bureau of Ukraine (NABU) is a state law enforcement agency charged with identifying, terminating, investigating, disclosing, and preventing corruption offenses. NABU is created by the President of Ukraine to counteract a criminal corruption offense committed by senior officials and endangering national security. According to Art. 16 of this Act, the duties of NABU include the use of operational-search activities, pre-trial investigation, search, seizure of funds, and other property that may be subject to confiscation or special confiscation. Cooperation, on terms of confidentiality, with persons reporting corruption offenses, informing society about the results of its work, international cooperation is also there. Article 216, paragraph 5, of Criminal Procedural Code 2012 (Ukr) defines substantive criminal offenses in which criminal investigations are carried out by NABU's detectives.

Appointment and recruitment procedures and budgetary independence are the most sensitive areas in which anti-corruption agencies can be 
exposed to political pressure (Sousa, 2009). Some Ukrainian scholars point out that the procedure for appointing persons to the Contest Commission in practice leads to the "political immunity" of senior officials for committing corruption offenses. By the results of work, Contest Commission sends two or three candidates to the post of Director of NABU. At the same time, Contest Commission personnel depends on the President of Ukraine, the pro-presidential Cabinet of Ministers of Ukraine, and the Verkhovna Rada (Fedorko, 2019). Thus, the main flaw "On the National Anti-Corruption Bureau of Ukraine" Act 2014 (Ukr) is its inconsistency in Art. 106 Constitution of Ukraine 1996 (Ukr) on the procedure for NABU's creation. Appointment and dismissal of his director, approval of Competition Commission according to Art. 106 Constitution of Ukraine 1996 (Ukr) not assigned to the powers of the President of Ukraine. However, Art. 6, 7 "On the National Anti-Corruption Bureau of Ukraine" Act 2014 (Ukr), contrary to Art. 106 Constitution of Ukraine 1996 (Ukr) granted to the President such powers.

Despite this, the President, with his decrees, formed the NABU and appointed Artem Sitnik as its director (Decree of the President of Ukraine No. 217/2015 2015 (Ukr); Decree of the President of Ukraine No. 218/2015 2015 (Ukr)). According to the Constitutional Court of Ukraine, changes to Art. 106 of the Constitution of Ukraine 1996 (Ukr) concerning the extension of the President's powers in these matters is contrary to the provisions of Art. 157 of the Constitution of Ukraine. They may violate the balance of constitutional powers between the President of Ukraine and the Cabinet of Ministers of Ukraine, effectively creating a parallel executive power subordinate to the President of Ukraine.

The creation and work of NABU, as a specialized anti-corruption state body for the termination, investigation, disclosure of corruption offenses, fully complies with the provisions of Resolution (97) 24, the UN Convention against Corruption. However, the commencement of its work, which did carry out in violation of the provisions of the national constitution, created substantiated doubts about further institutional independence of this body from other bodies of state power, in particular, the President of Ukraine. Independence and autonomy, freedom from improper influence are principles defined by Resolution (97)24. Subsequently, the doubts of the Ukrainian public about the independence of NABU from the President of Ukraine received their confirmation when Radio Liberty announced the fact of the night informal meeting of the director of NABU Sitnik with President Poroshenko in a private residence (Radio Liberty, 2018). Journalist Boyko in his publication, based on documents from the register of rights to real estate, cited data that in 2010, the head of the department at the Prosecutor's Office, A. Sitnik received from the local charity fund a two-room apartment in the suburbs of Kyiv as a present. According to the journalist, funds for the purchase of this apartment by charity fund came 
from the company of one of the suspects in a criminal case. At that time the criminal case has been investigated by the prosecutor's office headed by Sitnik (Boyko, 2018). According to the decision of the Rivne Court of Appeal, the Director of NABU Sytnyk has been brought to administrative responsibility for committing a corruption offense of violation of statutory restrictions on gifts (Kolomiets, 2019).

Starting from 2015, according to "On Amendments to Certain Legislative Acts of Ukraine to Ensure the Activities of the National Anti-Corruption Bureau of Ukraine and the National Agency for Corruption Prevention" Act 2015 (Ukr), General Prosecutor's Office of Ukraine (GPO) includes the Specialized Anti-Corruption Prosecutor's Office (SAP). SAP is an independent structural unit. SAP entrusts with the functions of overseeing the observance of laws during the conduct of operational-search activities, pre-trial investigation of NABU, maintenance of state prosecution in relevant proceedings. It represents the interests of a citizen and state in court in cases involving corruption.

Despite the creation of an autonomous anti-corruption body in GPO, the quality of procedural and out-of-procedure interaction between NABU and SAP is difficult to call acceptable. In this regard, an illustrative example is when in an aquarium stationed in the office of SAP's head Kholodnitskiy by NABU's officers had been installed a listening device within the framework of a pre-trial investigation. It concerned the extortion of a bribe of $\$ 2$ million for the release of a person arrested on suspicion of a corruption offense. The results of the listening cabinet of the head of SAP were promulgated in the national media, after which the public began to accuse Kholodnitsky of disclosing the data of pre-trial investigation to outsiders. However, at the end of 2018, all official allegations against Kholodnitsky were withdrawn, and the relevant criminal proceedings were closed (Nikolaenko, 2019). Besides, in September 2018, there was a case of use of violent actions by the Special Forces of NABU to SAP's prosecutors, which resulted in SAP accusing NABU of "illegally installed means of secretly withdrawal information" (Radio Liberty 2, 2018).

Considering these examples in the context of the principal-agent model, where a high-ranking officer of the anti-corruption body may act as a corrupt principal, the conclusions of Ledeneva, Bratu, Köker on the impracticality of principal-agent framework could be applied (Ledeneva et al., 2017). It is also confirmed by empirical data. Thus, $52 \%$ of detectives interviewed think that publications and facts about possible corruption offenses committed by anti-corruption officials hurt the psychological status of other employees. It influences the level of public confidence in the activities of such bodies and affects the success of the implementation of the anti-corruption policies. It also confirmed by the statistics below. 
Oleksandra Zakharova, Olena Harasymiv, Olga Sosnina, Oleksandra Soroka y Inesa Zaiets Comparative legal analysis of the anti-corruption policy in Ukraine and Poland

According to the statistics of GPO in 2018, only 9 indictments (7\%) from 132 criminal proceedings investigated by the NABU sent to court in the category of crimes related to unlawful profit (bribery) (Art. 368-369 of the Criminal Code of Ukraine). More than half, namely, 56 criminal proceedings of this category were closed by NABU in the absence of crime (General Prosecutor's Office of Ukraine, 2019). With the number of NABUs staff in 700 people, in 6 months of 2018, NABU sent to court indictments concerning of 2 people who hold public service positions in category "A" (top officials) (NABU, 2018). Such performance indicators of NABU and SAP do not correspond to the level of corruption in Ukraine according to CPI ranking. Such an example of a discrepancy between perception and reality regarding the measurement of corruption may be an argument in favor of some scholars who argue against the use of corruption indices for political or social purposes (Galtung, 2005; Ledeneva et al., 2017). However, such indicators may show the improper performance of pre-trial investigation and the prosecutor's guidance in relevant criminal proceedings by anticorruption law enforcement bodies. Therefore, an argument in favor of the creation of the High Anti-Corruption Court in Ukraine could be questionable. According to this argument, exclusively first-instance courts and not the low quality of work of anti-corruption bodies are the main obstacles in condemning top officials for corruption.

This confirms by the lack of practical implementation in 2018 of such an anti-corruption principle with Resolution (97) 24 as the seizure and deprivation of the proceeds of corruption offenses. Thus, according to the State Treasury Service of Ukraine in 2018 by court decisions on corruptionrelated cases confiscated only $\$ 5010$ with planned $\$ 170$ million (Ukrainian Pravda, 2019). A special item on the proceeds of confiscated funds and property for committing corruption-related offenses did withdraw by Government and Parliament. Applying Klitgaard's formula to this case in that the less accountability than the more corruption, the success of the work of anti-corruption bodies is called under reasonable doubt in 2019.

\subsection{National level: Poland}

Article 36 of the UN Convention against Corruption provides the existence of a body with the necessary independence, which specialized in combating corruption through law enforcement. In 2006, the Sejm (Polish Parliament) adopted "On the Central Anti-Corruption Bureau" Act, which provides the creation of an independent specialized anti-corruption body, the Central Anti-Corruption Bureau (CBA). Provisions of Art. 2 of this Act provides that CBA's tasks comprise in particular:

- recognition, prevention, and detection of criminal offences with the definite subject matter. 
- disclosure and prevention of non-observance of the provisions of legislation about restrictions on the conduct of business activities by persons performing public functions.

- disclosure of cases of non-observance of procedures, defined by the provisions of the law on taking decisions and implementation thereof within the scope of privatization and commercialization, financial support, an award of public contracts.

- the accuracy and veracity verification of asset declarations or declarations on the conduct of business activities by persons performing public functions.

In pursuance of the function of recognition, prevention and detection of criminal offenses, under Art. 14 of this Act CBA officers have rights: apprehend persons and search persons, premises according to procedures and circumstances specified in the provisions of the Criminal Procedure Code; conduct a body search, examine the contents of the luggage, stop vehicles and other means of transport as well as check the cargo in land, air and water means of transport in the event of a reasonable suspicion of a criminal or fiscal offence; observe and register, with the use of technical measures, the picture of events in public places and the sound accompanying such events in the course of performing operational intelligence undertaken according to the Act.

During the creation of CBA in Poland, the public, lawyers, and politicians have raised reasonable doubts about compliance provisions of "On the Central Anti-corruption Bureau" Act 2006 (Pol) to provisions of the Polish Constitution. It was similar to NABU's creation case in Ukraine. But in the case of the CBA, these issues did not deal with the appointment of the head of the body, but about the legal definition of corruption and principles of collecting personal data and conducting control activities. In 2009, the Constitutional Court of Poland declared unconstitutional, which did not comply with the Convention for the Protection of Human Rights and Fundamental Freedoms, done at Rome on Nov. 4, 1950. It abolished provisions of Art. 1 of Act in the scope in which the corruption in the private sector recognizes the behavior of any person who does not have a public function, without restricting this term using socially harmful reciprocal premises. It also abolished provisions of Art. 22 of Act, to the extent that it enables the CBA to collect data on the protection of personal data and the use of such data and information obtained as a result of performing operational and intelligence activities without the knowledge and consent of the person concerned - without guaranteeing instruments to control the manner of data storage and verification and how to remove data unnecessary. Finally, it abolished the provisions of Art. 40 of Act, to the extent that it permits inspections of real estate or other assets without specifying the manner of using and storing data obtained in this way, in 
particular regarding third parties not obliged to file asset declarations (Judgment K 54/O7). As a result of this judgment, the institution of the proxy for personal data protection established. This institution acts as the administrator of information security in the service and consists of, among others, annual reports on the status of personal data protection in the CBA (Fundacją Panoptykon, 2015).

In 2016, 32 (52\%) of the 62 completed CBA criminal cases, materials with indictments were transferred to the court (CBA, 2016), indicating a more efficient work of this body, comparing with the corresponding indicator of NABU (7 \%). At the same time, we also found critical publications about certain facts of CBA executives' inactivity over the past years. In particular, an officer of the Polish military counterintelligence Jarosław Pieczonka accused the former CBA head of Mariusz Kamiński in the absence of reaction to his reports about facts of influence by Russian intelligence agent on the head of CBA department in Gdansk (Pieczonka, 2016). Moreover, the inspection of GPO of Poland showed that since the creation of CBA until June 30, 2015, the prosecutors questioned 5 decisions of the CBA head. Decisions regarded the refusal to release CBA officers from the obligation not to disclose classified information for purposes of pre-trial investigation. 2 of them were considered correct (Seremet, 2016).

\subsection{Anti-corruption strategies, programs. The state of their implementation in Ukraine and Poland}

In order to implement the Guiding Principles for the Fight Against Corruption, taking into account the proposals made by GRECO to Ukraine, in particular, "On Principles of Prevention and Counteraction Corruption" Act adopted, and National Anti-Corruption Strategy (NAS) for 20112015 was approved by Decree of the President of Ukraine No.1001/2011. Following the provisions of NAS, the State Program for Prevention and Counteraction Corruption 2011-2015 was approved (Resolution of the Cabinet of Ministers No.1240 2011 (Ukr)). Its purpose was to introduce mechanisms for reducing corruption in Ukraine. For this ministries, other authorities obliged to submit to the Ministry of Justice annually information on the state of implementation of State Program for its generalization and inclusion into a report on the results of the implementation of measures on corruption prevention. However, despite all these measures, in 2013, TI identified the ineffectiveness of State Program implementation based on the results of public monitoring. Among the main reasons for the ineffectiveness of State Program were named:

- lack of adequate funding for most program measures and clear indicators for their implementation. 
- lack of proper coordination of performers, the inconsistency of individual tasks with planned activities.

- the limited capacity of performers, low level of performance discipline.

- lack of a public request for reforms.

- putting responsibility for the implementation of anti-corruption measures on bodies that are affected by corruption (Khmara, 2013). Last reason in the context of the principal-agent model confirmed it's impracticality in Ukraine.

Next Act, which identified the priority measures to prevent and counteract corruption, which should form the basis for further reform in this area, is "On the Principles of State Anti-Corruption Policy in Ukraine (AntiCorruption Strategy) for 2014-2017" Act 2014 (Ukr). Art. 18 "Prevention of Corruption" Act 2014 (Ukr) provides that the principles of anti-corruption policy (Anti-Corruption Strategy) determined by the parliament. AntiCorruption Strategy implemented through the implementation of a state program developed by NACP and approved by the Cabinet of Ministers. In compliance with these provisions adopted Resolution of the Cabinet of Ministers No.265 2015 (Ukr).

The provisions of this Act stated that the previous NAS for 2011-2015 did not become an effective tool of anti-corruption policy. It is true primarily because of the absence of clear indicators of state and effectiveness of its implementation, the absence of a mechanism for monitoring and evaluation ('On the Principles of State Anti-Corruption Policy in Ukraine (Anti-Corruption Strategy) for 2014-2017' Act 2014 (Ukr)).

Anti-Corruption Strategy for 2014-2017 identified some problems and measures to address them. In particular, the following key issues identified: lack of legislative, institutional basis for the formation and implementation of anti-corruption policy based on cooperation between state bodies and the public; the democratic nature of the political system in general and the electoral process in particular; honest public service; corruption prevention in activities of executive authorities, in the field of public procurement, in the judiciary and criminal justice bodies, in the private sector; lack of access to information; formation of a negative attitude towards corruption among the population. The State Program on the implementation of the AntiCorruption Strategy in Ukraine for 2015-2017, for each section of the State Anti-Corruption Policy framework, were approved tasks and measures for its implementation. Established deadlines, bodies responsible for each task, indicators for implementation, sources of funding provided.

According to NACP analytical report on the implementation of the AntiCorruption Strategy for 2014-2017 and the State Program on Implementing 
of Anti-Corruption Strategy, as of the second quarter of 2017, 112 measures of the State Program implemented, 38 partially implemented, and 23 completed in the course of implementation. Overall, the degree of implementation of measures assessed only $64 \%$, only $27 \%$ of State Program measures implemented on time (NACP, 2017). Among the reasons for this low quality of its implementation, it may note, the passive attitude of the responsible authorities, the full launch of the newly created anti-corruption bodies (NACP, NABU, SAP) only at the end of 2015 - beginning of 2016.

The main problem of the present day in Ukraine concerning the legislative provision of the Anti-Corruption Strategy is that in 2019 the Ukrainian parliament did not adopt "On Anti-corruption Strategy for 20182020" Draft Act. We think that a part of the responsibility lies with the government, which only on April 26, 2018, submitted to the parliament this bill. Only 18.09.2018 it was included to parliament session agenda. Where the law has little credibility or serves the interests of corrupt figures and where legitimate alternatives to corrupt dealings are scarce, crime-andpunishment strategies may have little success (Johnston, 2011). Thus, in addition to the above-mentioned reasons for the ineffective implementation of the Anticorruption Strategy for 2014-2017, one can add the lack of political will on the issues of the formation and implementation of clear legislative measures aimed at reducing corruption and further promotion of anti-corruption initiatives in Ukraine.

Considering Poland's legislation in this area can be noted that art. 19 "On the principles of development policy" Act 2006 (Pol) states that the state development program, prepared by the relevant minister, is approved by the Council of Ministers. In pursuance of this provision, the Council of Ministers of Poland adopted the Anti-Corruption Program 2018-2020. It defines the main and special objectives of the program, the scale for measuring the success of the program objectives, the mechanisms for implementing the program, the action plan for each task, the implementation and evaluation of the program implementation division at the level of responsible subjects (program coordinators, a team appointed by the prime minister, the Council of Ministers). The main goals of the Polish Anti-Corruption Program include: strengthening preventive and educational activities; improvement of mechanisms for controlling corruption threats and monitoring of legal norms in the area of counteraction to corruption crimes; intensification of co-operation and coordination between law enforcement agencies in this area (p. 3.1 Anti-Corruption Program 2018-2020 2017 (Pol)).

One of the criteria for assessing the implementation of the AntiCorruption Program, the Polish government has identified the need to implement at least $80 \%$ of planned activities in each task in the middle of the third year of Program's implementation (p.3.3 Anti-Corruption Program 2018-2020 2017 (Pol)). Comparing this indicator with the degree 
(64\%) of implementation of Ukrainian Anti-Corruption Strategy for 20142017, we can conclude that, according to Polish standards of evaluation, the implementation of the Anti-Corruption Strategy for 2014-2017 in Ukraine cannot be considered successful. Instead, it should note that the potential threats to the implementation of the Anti-Corruption Program 20182020 in Poland, as in Ukraine, include such a factor as the lack of political agreement and will to implement the legal provisions on prevention and counteraction corruption.

\section{Conclusions}

As a result of the comparative legal analysis of the anti-corruption policy of Ukraine and Poland, as well as the practice of its implementation, established that the mere fact of joining one or another country to international anti-corruption treaties (Civil Law Convention on Corruption, Criminal Law Convention on Corruption, Resolution (97) 24, Resolution (99) 5 , UN Convention against Corruption, etc.) is not a guarantee of successful implementation of anti-corruption policy within the country. Indeed, we can agree that studied countries have different syndromes of corruption, which effects on results of the implementation of anti-corruption policies. However, identified individual elements of the anti-corruption policies are also affected on such results. The key to successful anti-corruption efforts is the existence of modern national anti-corruption legislation that is best suited to meet the requirements and recommendations relied on by the state in the relevant international treaties.

\section{Table 1}

Comparative characteristics on the presence / absence of individual elements of the anti-corruption policy of Ukraine and Poland

\begin{tabular}{|l|c|c|}
\hline & Ukraine & Poland \\
\hline $\begin{array}{l}\text { (GRECO, Criminal Law Convention on Corruption, } \\
\text { UN Convention against Corruption) Membership }\end{array}$ & + & + \\
\hline The existence of national anti-corruption legislation & + & + \\
\hline $\begin{array}{l}\text { Existence of independent/autonomous specialized } \\
\text { anti-corruption bodies }\end{array}$ & + & + \\
\hline $\begin{array}{l}\text { Availability of legislation on anti-corruption state } \\
\text { strategy/program/plan }\end{array}$ & + & + \\
\hline $\begin{array}{l}\text { Presence of indicator for assessing the success of } \\
\text { implementing an anti-corruption state strategy/ } \\
\text { program/plan }\end{array}$ & - & + \\
\hline
\end{tabular}


Oleksandra Zakharova, Olena Harasymiv, Olga Sosnina, Oleksandra Soroka y Inesa Zaiets Comparative legal analysis of the anti-corruption policy in Ukraine and Poland

\begin{tabular}{|l|c|c|}
\hline $\begin{array}{l}\text { Presence of an anti-corruption state strategy/ } \\
\text { program/plan in force for 2019-2020 }\end{array}$ & - & + \\
\hline $\begin{array}{l}\text { CPI Ranking (2020) (Transparency international, } \\
\text { 2020) }\end{array}$ & $\mathbf{1 1 7}$ & $\mathbf{4 5}$ \\
\hline
\end{tabular}

Source: own elaboration

The system of legislative regulation of anti-corruption policy of Poland distinguishes vis-a-vis neighbouring countries of the East European region (Ukraine) by the list of its elements. These include the existence of independent specialized anti-corruption bodies that are not affected by corruption itself, the existence of an anti-corruption state strategy/program that is not interrupted and contains a list of specific tasks, terms, bodies responsible for each task, performance indicators, sources of funding, the existence of clear indicators of evaluating the success of the implementation of the anti-corruption state strategy / program (Table 1). In this context, also founded that the independence from external political influence, the effective use in the practice of respective powers provided to specialized anticorruption bodies by national legislation, and the availability of effective cooperation between these bodies, is equally important. Unfortunately, these blemishes currently do not allow Ukraine to successfully implement its anti-corruption policy, as evidenced in particular by sociological data, CPI Ranking, as well as statistics about NACP and NABU activities in 20172020.

\section{Bibliographic References}

COUNCIL OF EUROPE. 1999. Civil Law Convention on Corruption. 1999. Available online. In: https://www.coe.int/en/web/conventions/fulllist/-/conventions/treaty/174. Consultation date: 28/03/2021.

CONFORTY. B. 1993. International Law and the Role of Domestic Legal System. Dorderecht, Netherlands.

CONSTITUTION OF UKRAINE. 1996. On June 28. Available online. In: https://zakon.rada.gov.ua/laws/show/254\%Do\%BA/96-\%Do\%B2\% D1\%80\#Text. Consultation date: 28/03/2021.

COUNCIL OF EUROPE. 1999. Criminal Law Convention On Corruption. 1999. Available online. In: https://www.coe.int/en/web/conventions/fulllist/-/conventions/treaty/173. Consultation date: 28/03/2021.

CRIMINAL PROCEDURAL CODE OF UKRAINE. 2012. Available online. In: http://zakon.rada.gov.ua/laws/show/4651-17. Consultation date: 28/03/2021. 
CRIMINAL CODE OF UKRAINE. 2001. Available online. In: https://zakon. rada.gov.ua/laws/show/2341-14. Consultation date: 28/03/2021.

DECREE OF THE PRESIDENT OF UKRAINE No. 1001/2011. 2011. (On the National Anti-Corruption Strategy for 2011-2015). 2011. Available online. In: https://zakon.rada.gov.ua/laws/show/1001/2011. Consultation date: 28/03/2021.

DECREE OF THE PRESIDENT OF UKRAINE No. 217/2015. 2015. (On the Establishment of the National Anti-Corruption Bureau of Ukraine).

DECREE OF THE PRESIDENT OF UKRAINE No. 218/2015. 2015. (About the appointment of A. Sitnik as Director of the National Anti-Corruption Bureau of Ukraine).

ON AMENDMENTS TO CERTAIN LEGISLATIVE ACTS OF UKRAINE TO ENSURE THE ACTIVITIES OF THE NATIONAL ANTI-CORRUPTION BUREAU OF UKRAINE AND THE NATIONAL AGENCY FOR CORRUPTION PREVENTION. 2015. Available online. In: https:// zakon.rada.gov.ua/laws/show/198-19. Consultation date: 28/03/2021.

COUNCIL OF EUROPE. 1997. Resolution (97) 24 On the Twenty Guiding Principles For The Fight Against Corruption. Available online. In: https://polis.osce.org/node/4681. Consultation date: 28/03/2021.

APPENDIX TO RESOLUTION. COUNCIL OF EUROPE. 1999. Resolution (99) 5 Establishing the Group of States Against Corruption (GRECO). 1999. Available online. In: https://rm.coe.int/168o6cd24f. Consultation date: 28/03/2021.

RESOLUTION OF THE CABINET OF MINISTERS No. 1240. 2011. (On Approval of State Program for Prevention and Counteraction Corruption 2011-2015) 2011 (Ukr). Available online. In: https://zakon.rada.gov.ua/ laws/show/1240-2011-\%Do\%BF. Consultation date: 28/03/2021.

RESOLUTION OF THE CABINET OF MINISTERS No. 265. 2015. (On Approval of the State Program for Implementing Principles of State AntiCorruption Policy in Ukraine (Anti-Corruption Strategy) for 2015-2017). 2015. Available online. In: http://zakon.rada.gov.ua/laws/show/2652015-\%Do\%BF. Consultation date: 28/03/2021.

UNITED NATIONS CONVENTION AGAINST CORRUPTION. 2003. United Nations Office on Drugs and Crime. Available online. In: https://www. unodc.org/documents/treaties/UNCAC/Publications/Convention/o850026_E.pdf. Consultation date: 28/03/2021. 
ANTI-CORRUPTIONPROGRAM 2018-2020. 2017. Available online.In: http:// gamma.infor.pl/zalaczniki/mpo/2018/003/mpo.2018.003.012.0001. pdf. Consultation date: $28 / 03 / 2021$.

BANAKHIEVICH, Yurii. 2017. Poland and corruption: The life of officials will be "discovered" by law. Available online. In: https://www.ukrinform. ua/rubric-world/2222765-polsa-ikorupcia-zitta-cinovnikiv-vidkriutzakonom.html. Consultation date: 28/03/2021.

BARDACHOV, Yurii. 2014. Anti-corruption reform in Ukraine as a significant factor ensuring national security. Theory and Practice of Public Administration and Local Government 2014 (2). Available online. In: http://nbuv.gov.ua/UJRN/Ttpdu_2014_2_3. Consultation date: 28/03/2021.

BOYKO, Vladimir. 2018. The apartment issue of Artem Sitnik. Available online. In: https://ord-ua.com/2018/o4/13/kvartirne-pitannya-artemasitnika/. Consultation date: 28/03/2021.

CBA. 2016. Map of corruption. Available online. In: https://cba.gov.pl/ftp/pdf/ Mapa\%20korupcji\%202016.pdf. Consultation date: 28/03/2021.

CHRISTENSEN, John; SHAXSON, Nicholas; BAKER, Raymond. 2008. Catching up with corruption. The American Interest vol. 4 (1). Available online. In: https://www.the-american-interest.com/2008/09/01/ catching-up-with-corruption/. Consultation date: 28/03/2021.

DE VEL, Guy; CSONKA, Peter. 2002. The Council of Europe Activities against Corruption. Corruption, Integrity and Law Enforcement. Ed. by Cyrille Fijnaut and Leo Humberts. Kluwer Law International. The Hague/ London/New York.

FALKNER, Gerda; TREIB, Oliver. 2008. "Three Worlds of Compliance or Four? The EU-15 Compared to New Member States" In: Journal of Common Market Studies. Vol. 2, No. 46, pp. 293-313.

FEDORKO, Oleh. 2019. "Independence of National Anti-corruption Bureau: myth or reality". In: Journal of Actual problems of domesticjurisprudence 2019: Special issue. pp. 108-111. Available online. In: http://apnl.dnu. in.ua/2019/31.pdf. Consultation date: 28/01/2021.

FUNDACJA PANOPTYKON. 2015. The Constitutional Court with the eyes of Panoptykon. Available online. In: https://panoptykon.org/wiadomosc/ trybunal-konstytucyjny-okiem-panoptykonu. Consultation date: 28/03/2021. 
GALTUNG, Fredrik. 2005. Measuring the immeasurable: boundaries and functions of (macro) corruption indices. Available online. In: http:// www.anti-corruption.org/wp-content/uploads/2016/11/GaltungMeasuring-the-Immeasurable.pdf. Consultation date: 29/03/2021

GENERAL PROSECUTOR'S OFFICE OF UKRAINE. 2019. Uniform report on criminal offenses in January-December 2018. Available online. In: https://www.gp.gov.ua/ua/stst2011.html?dir_id= 113653\&libid=100820\&c=edit\&_c=fo. Consultation date: 28/03/2021.

GRECO. 2017. Evaluation report Ukraine. Available online. In: https:// rm.coe.int/grecoeval4rep-2016-9-fourth-evaluation-round-corruptionprevention-in-/1680737207. Consultation date: 28/03/2021.

HROMADSKE TV. 2018. Five NACP scandals: what the head of the agency Natalia Korchak remembered. Available online. In: https://hromadske. ua/posts/5-skandaliv-nazk-chym-zapamiatalasia-ochilnytsiaahentstva-nataliia-korchak. Consultation date: 28/03/2021.

JOHNSTON, Michael. 2011. Why do so many Anti-corruption efforts fail. Available online. In: http://www.law.nyu.edu/sites/default/ files/upload_documents/NYU-Annual-Survey-67-3-Johnston.pdf. Consultation date: $28 / 03 / 2021$.

JUDGMENT OF THE CONSTITUTIONAL COURT OF POLAND. 2009. Ref. K 54/o7 (June 23, 2009). Available online. In: https://trybunal.gov. $\mathrm{pl} /$ postepowanie-i-orzeczenia/wyroki/art/4929-definicja-ustawowakorupcji-zasady-zbierania-danych-osobowych-i-prowadzeniadzialalnosci-kontro. Consultation date: 28/03/2021.

KHMARA, Oleksij. 2013. The state program to prevent and combat corruption for 2011-2015 worth more than UAH 820 million may remain in the status of "filkin's diploma". Available online. In: https://m.tyzhden.ua/ publication/78657. Consultation date: 28/01/2021.

KLITGAARD, Robert; MACLEAN-ABAROA, Ronald; PARRIS H., Lindsey. 2000. Corrupt cities: a practical guide to cure and prevention. Institute for Con6temporary Studies. Oakland, California.

KOLOMIETS, Victoria. 2019. «Director of the National Anti-Corruption Bureau of Ukraine Sytnyk entered in the register of corrupt officials». Available online. In: https://hromadske.ua/posts/direktora-nabu-sitnika-vneslido-reyestru-korupcioneriv Consultation date: 28/01/2021.

LANDELL-MILLS, Pierre. 2013. Citizens against corruption. Report from the front line. Partnership for Transparency Funding. UK. 
LEDENEVA, Alena; BRATU, Roxana; KÖKER, Philipp. 2017. "Corruption studies for the twenty-first century: paradigm shifts and innovative approaches" In: The Slavonic and East European Review. Vol. 1, No. 95, pp. 1-20.

NABU. 2018. NABU report for the first half of 2018. Available online. In: https://nabu.gov.ua/sites/default/files/reports/zvit_10.08.2018_sayt. pdf. Consultation date: $28 / 03 / 2021$.

NACP. 2017. Analytical Report on the implementation of the Anti-Corruption Strategy for 2014-2017 and the State Program on the Implementation of the Anti-Corruption Strategy Principles. Available online. In: https:// nazk.gov.ua/sites/default/files/docs/2017/\%Do\%BC. Consultation date: $28 / 03 / 2021$.

NIKOLAENKO, Tetiana. 2019. The quiet death of Holodnitsky fishes. Available online. In: https://lb.ua/news/2019/o1/18/417465_tiha_smert_ribok_ holodnitskogo.html. Consultation date: 28/03/2021.

OBURA, Ken. 2014. Unmasking the phenomenon of corruption: perspectives from legal theory. SPECULUM JURIS 2014 (1). Available online. In: https://web.archive.org/web/20170713101207/http://www.ufh.ac.za/ speculumjuris/files/pdf/SJ1614_1.pdf. Consultation date: 28/03/2021.

ON ANTI-CORRUPTION STRATEGY FOR 2018-2020. 2018. Available online. In: http://w1.c1.rada.gov.ua/pls/zweb2/webproc4_1?pf3511=63942. Consultation date: 12/03/2021. Consultation date: 28/03/2021.

ON THE CENTRAL ANTI-CORRUPTION BUREAU. 2006. Available online. In: http://prawo.sejm.gov.pl/isap.nsf/DocDetails.xsp?id= WDU20061040708. Consultation date: 28/03/2021.

ON THE NATIONAL ANTI-CORRUPTION BUREAU OF UKRAINE. 2014. Available onlaine. In: https://zakon.rada.gov.ua/laws/show/1698-18. Consultation date: 28/03/2021.

ON THE PRINCIPLES OF DEVELOPMENT POLICY. 2006. Available online. In: http://www.lexlege.pl/ustawa-o-zasadach-prowadzenia-politykirozwoju/. Consultation date: 28/03/2021.

ON THE PRINCIPLES OF STATE ANTI-CORRUPTION POLICY IN UKRAINE (ANTICORRUPTION STRATEGY) FOR 2014-2017. 2014. Available online. In: http://zakon.rada.gov.ua/laws/show/1699-18/. Consultation date: $28 / 03 / 2021$.

PIECZONKA, Jarosław. 2016. Miami - former counterintelligence agent: For the previous PiS government, the CBA's activities were good, but 
the implementation was poor. Natemat.pl. Available online. https:// natemat.pl/178315,majami-byly-agent-kontrwywiadu-za-poprzednichrzadow-pis-kierunki-dzialan-cba-byly-dobre-ale-realizacja-slaba. Consultation date: 28/03/2021

POLIKOVSKAYA, Yulia. 2017. One-third of Ukrainians find justification for corruption to resolve personal cases. Available online. In: https://zaxid. net/33_ukrayintsiv_vvazhayut_koruptsiyu_chastinoyu_traditsiy_ n1439644. Consultation date: $28 / 03 / 2021$.

POPE, Jeremy. 2011. Fighting Corruption: Elements of the System of State Integrity. Planet-Print Ltd. Rivne, Ukraine.

POYNTING, Scott; WHYTE, David. 2017. "Special edition: Corruption downunder - guest editors' introduction" In: International Journal for Crime, Justice and Social Democracy. Vol. 6, No.4, pp. 1-11.

PREVENTION OF CORRUPTION. 2014. Available online. In: https://zakon. rada.gov.ua/laws/show/1700-18. Consultation date: 28/03/2021.

RADIO LIBERTY 2. 2018. SAP claims clashes with NABU. Available online. In: https://www.radiosvoboda.org/a/news-nabu-sap/29498763.html. Consultation date: 28/03/2021.

RADIO LIBERTY. 2018. "Schemes" captured the night at Sitnik's home at President Poroshenko. Available online. In: https://www.radiosvoboda. org/a/news-schemes/29359771.html. Consultation date: 28/03/2021.

SEREMET, Andrzej. 2016. Report of the Prosecutor General from the annual activity in 2015. General Prosecutor's office. Available online. In: https://pk.gov.pl/wp-content/uploads/2016/o4/901ad6ofac337 boa1fo96eacdocb757f.pdf. Consultation date: 28/03/2021.

UNITED NATIONS OFFICE ON DRUGS AND CRIME. 2018. Signature and Ratification Status. Available online. In: https://www.unodc.org/unodc/ en/corruption/ratification-status.html. Consultation date: 28/03/2021.

SOUSA, Luis. 2009. "Anti-Corruption Agencies: Between Empowerment and Irrelevance" In: Crime, Law and Social Change. Vol. 53, No. 1, pp. 5-22.

TRANSPARENCY INTERNATIONAL. 2020. The global coalition against corruption: corruption perceptions index 2020. In: https://www. transparency.org/en/cpi/2020/index/nzl. Consultation date: 28/01/2021.

UKRAINIAN PRAVDA. 2016. NACP has officially been left without a quorum - Chumak left the agency. Available online. In: https://www. 
eurointegration.com.ua/news/2016/03/3/7045757/. Consultation date: 28/01/2021.

UKRAINIAN PRAVDA. 2019. For the whole of 2018, \$ 5,000 were confiscated from corrupt officials. Available online. In: https://www.pravda.com.ua/ news/2019/01/18/7204151/. Consultation date: 28/01/2021. 
Vol. 39 N $^{\circ} 69$

Esta revista fue editada en formato digital y publicada en julio de 2021, por el Fondo Editorial Serbiluz, Universidad del Zulia. Maracaibo-Venezuela 